\title{
UPAYA MEWUJUDKAN LANSIA TANGGUH MELALUI BINA KELUARGA LANSIA (STUDI DESKRIPTIF DI BKL KECUBUNG)
}

\author{
Bigi Pangestuti \\ Pendidikan Nonformal, Universitas Negeri Yogyakarta \\ laskarpnfi@gmail.com
}

\begin{abstract}
Abstrak
Penelitian ini bertujuan mendeskripsikan upaya mewujudkan lansia tangguh di BKL Kecubung, peran kader dan keluarga lansia, faktor pendukung dan penghambat, serta hasil kegiatan lansia tangguh. Penelitian ini merupakan penelitian kualitatif dengan metode deskriptif. Subyek penelitian ini pengelola BKL Kecubung, narasumber, lansia dan keluarganya. Teknik pengumpulan data dengan observasi, wawancara dan dokumentasi. Teknik yang digunakan dalam analisis data adalah analisis kualitatif oleh Milles dan Huberman yaitu reduksi data, penyajian data dan penarikan kesimpulan. Hasil penelitian menunjukkanupaya mewujudkan lansia tangguh meliputi perencanaan, pelaksanaan dan penilaian. Kader BKL Kecubung berperan di dalamdan luar kegiatan. Faktor pendukungnya adalah semangat lansia, kaderaktif dan ramah, kepercayaan pemerintah setempat, dukungan mitra. Faktor penghambatnya adalah keterbatasan sarana prasarana, kondisi fisik lansia, keterbatasan pendanaan, kondisi geografi, dan kurangnya partisipasi keluarga. Hasil kegiatan adalah muncul kebiasaan positif, memiliki kegiatan mengasah ingatan, harapan menikmati usia tuanya dengan kemandirian, dan terjalin hubunganyang baik.
\end{abstract}

Kata kunci: bina keluarga lansia, lansia, kader, keluarga

\begin{abstract}
This study aims to describe efforts to create resilient elderly people in BKL Kecubung, the role of cadres and elderly families, supporting and inhibiting factors, and the results of resilient elderly activities. This research is a qualitative research with descriptive method. The subjects of this study were the managers of the BKL Kecubung, resource persons, the elderly and their families. Data collection techniques by observation, interview and documentation. The technique used in data analysis is qualitative analysis by Milles and Huberman, namely data reduction, data presentation and conclusion drawing. The results of the study show that efforts to create resilient elderly people include planning, implementation and evaluation. BKL cadres play a role in and outside the activity. Supporting factors are the spirit of the elderly, active and friendly cadres, trust of local government, partner support. The inhibiting factors are limited infrastructure, the physical condition of the elderly, limited funding, geographical conditions, and lack of family participation. The results of these activities are positive habits that appear, have activities to hone memories, hope to enjoy old age with independence, and established good relationships.
\end{abstract}

Keywords: elderly family development, elderly, cadres, family

PENDAHULUAN

Indonesia sebagai negara berkembang telah mengupayakan program-program pembangunan dalam berbagai bidang yang bertujuan untuk kemajuan wilayah dan kesejahteraan rakyatnya. Keberhasilan program pembangunan yang telah dilaksanakan, terutama dalam bidang kesehatan dan kesejahteraan sosial berdampak pada meningkatnya angka rata-rata usia harapan hidup penduduk (Partini, 
2011:3). Sehingga tidak dapat dipungkiri lagi bahwa jumlah penduduk lansia di Indonesia bertambah lebih cepat dan meningkat setiap tahunnya.

Jumlah penduduk lansia di Indonesia menurut Biro Pusat Statistik dalam Sensus Penduduk tahun 2015 mencapai angka 21,68 juta jiwa atau $8,43 \%$ dari jumlah penduduk Indonesia dengan usia harapan hidup mencapai 70, 7 tahun. Diperkirakan jumlah tersebut akan meningkat setiap tahunnya dengan proyeksi dalam kurun waktu 2030-2035 akan mencapai angka 48,20 juta jiwa atau $15,77 \%$ dari jumlah penduduk Indonesia dengan usia harapan hidup penduduk mencapai 72,2 tahun (Proyeksi Penduduk Indonesia, BPS : 2013).

DIY menempati urutan pertama jumlah penduduk lansia tertinggi di Indonesia. Pemerintah DIY mencatat jumlah penduduk lansia berdasarkan hasil Sensus Penduduk pada tahun 2015 yaitu sebanyak $13,46 \%$ dari total penduduk atau sebanyak 448.223 jiwa dan diperkirakan jumlah lansia mencapai $14,7 \%$ pada tahun 2020 dan meningkat menjadi $19,5 \%$ pada tahun 2035. (Badan Pusat Statistik, 2013). Jumlah lansia yang semakin meningkat ini tentunya akan berdampak pula pada meningkatnya angka ketergantungan lansia.

Pada masa usia lanjut, manusia melalui proses menua dan akan mengalami degenerasi atau kemunduran dari segi kemampuan ekonomi, fisik, psikologis dan sosial. Sehingga dengan menurunnya kondisi lansia dari berbagai segi tersebut maka akan memunculkan banyak permasalahan.

Selama ini pemerintah diakui telah menunjukkan keseriusan dalam menangani banyaknya permasalahan pada lansia. Pada tahun 1998 pemerintah telah mengeluarkan Undang-Undang Nomor 13 Tahun 1998 tentang Kesejahteraan Lanjut Usia. Selanjutnya diaplikasikan melalui Peraturan Pemerintah Nomor 43 Tahun 2014 tentang Upaya Peningkatan Kesejahteraan Sosial Lanjut Usia dan Peraturan Menteri Sosial Nomor 19 Tahun 2012 tentang Pedoman Pelayanan Sosial Lanjut Usia. Pemerintah juga menginisiasi pembentukan Komisi Nasional dan Komisi Daerah Lanjut Usia melalui Keputusan Presiden Nomor 52 Tahun 2004 dan Peraturan Menteri Dalam Negeri Nomor 6o Tahun 2008. Upaya peningkatan kesejahteraan sosial lansia adalah serangkaian kegiatan yang dilaksanakan secara terkoordinasi antara pemerintah dan masyarakat untuk memberdayakan lansia agar lansia tetap dapat melaksanakan fungsi sosialnya dan berperan aktif secara wajar dalam hidup bermasyarakat, berbangsa dan bernegara. Sedangkan program-program pemberdayaan dan pelayanan sosial bagi lansia yang dilaksanakan oleh pemerintah dapat dikelompokkan menjadi tiga yaitu Program Pelayanan Sosial di Dalam Panti, Program Pemberdayaan dan Pelayanan Sosial di Luar Panti, dan Kelembagaan Sosial dan Aksestabilitas Penduduk Lansia Lainnya. Semuanya telah mencakup berbagai bidang seperti bidang sosial, pendidikan, ekonomi maupun kesehatan.

Selain upaya dari pemerintah, diperlukan juga upaya untuk memberikan edukasi, motivasi dan informasi tentang persiapan memasuki dan menjalani hari tua bagi lansia maupun keluarganya. Sehingga dukungan dari pihak keluarga lansia sangat dibutuhkan. Karena salah satu fungsi keluarga adalah fungsi cinta kasih. Keluarga merupakan support system utama bagi lansia dalam mempertahankan kesehatannya. Peranan keluarga dalam perawatan lansia antara lain menjaga atau merawat lansia, mempertahankan dan meningkatkan 
status mental, mengantisipasi perubahan sosial ekonomi, serta memberikan motivasi dan memfasilitasi kebutuhan spiritual bagi lansia.

Di Kabupaten Gunungkidul, banyak kasus gantung diri yang mayoritas pelakunya adalah lansia. Menurut Ida Rochmawati menyatakan bahwa angka bunuh diri di Gunungkidul memprihatinkan. Tren bunuh diri di Gunungkidul, terlihat naik dari tahun ke tahun. Angka tersebut masih didominasi oleh usia lanjut atau di atas 60 tahun dengan $41 \%$, sementara sisanya dewasa 24\%, 30\% remaja dan anak-anak 5\%. (tribunjogja.com)

Fenomena lansia gantung diri di Gunungkidul ini merupakan dampak karena tekanan psikis yang dialami lansia akibat hidupnya yang kesepian. Lansia banyak yang hidup sendiri karena ditinggalkan anaknya merantau ke luar kota, seperti ke Jakarta, Tangerang, Bandung dan sebagainya. Banyak usia produktif di Gunungkidul yang lebih memilih merantau karena alasan banyaknya lapangan pekerjaan di kota tujuan daripada di daerahnya. Sehingga mereka meninggalkan orang tuanya sendiri di rumah dan hanya pulang sesekali waktu. Lansia merasa kesepian, tidak ada tempat berbagi permasalahannya, sehingga timbul penyakit-penyakit psikis maupun fisik dan mereka memilih untuk mengakhiri hidupnya, salah satunya dengancara gantung diri.

Adanya pola kebiasaan masyarakat di Gunungkidul yang memilih menitipkan anaknya kepada orangtuanya sementara dirinya bekerja merantau di luar kota juga menjadi permasalahan bagi lansia. Keberadaan cucu bagi lansia di rumahnya memang dapat menimbulkan dampak positif maupun negatif. Merawat sang cucu misalnya, hal ini dapat menjadi hal positif tetapi juga negatif. Apabila lansia mampu merawatnya dengan baik dan tulus maka lansia dapat senang dan bahagia bersama cucunya. Namun apabila lansia kesulitan merawatnya, maka hal ini hanya akan menjadi bebanmereka, baik dari segi psikis maupun ekonomi lansia. Walaupun dari segi ekonomi, sang anak juga memberikan penghasilan kepada lansia untuk biaya kehidupan cucunya. Hari tua lansia hanya akan diisi dengan beban merawat cucu-cucunya.

Selain pola kebiasaan itu, juga ada kebiasaan dalam keluarga di Gunungkidul yang melarang anak perempuan terkecil di dalam keluarganya untuk pergi merantau. Ia tidak boleh meninggalkan rumah orangtuanya bahkan ketika ia sudah menikah sekalipun. Hal ini dapat menjadi jaminan kepastian dan rasa aman bagi lansia karena dengan masih adanya anak di rumahnya, di hari tuanya nanti sang anak perempuan ini diharapkan dapat merawat dan menjaga orang tuanya. Namun ada juga permasalahannya, misalnya dalam hal perbedaan pemikiran dan berkomunikasi antara yang tua dan muda sehingga dapat memicu perselisihan di dalam keluarga.

Banyak lansia di Gunungkidul yang terserang penyakit stroke dan jantung. Ironisnya mayoritas dari mereka adalah lansia yang berpendidikan dan pensiunan PNS. Hal ini dapat terjadi karena ketidaksiapan mereka memasuki hari tuanya. Dahulu mereka sibuk bekerja dan masih memiliki banyak teman, namun setelah pensiun banyak aktivitas yang berkurang, merasa kehilangan (kedudukan, kekuasaan, teman, pendapatan, keluarga) dan jarang yang berperan di dalam masyarakat. Sehingga lansia yang tidak siap akan menjadi stress dan sakit-sakitan. 
Sebagai daerah yang memiliki jumlah lansia terbanyak se-Indonesia, sudah semestinya DIY mengupayakan berbagai macam program yang melibatkan pihakswasta, masyarakat maupun keluarga untuk mewujudkan lansia yang tangguh. Salah satunya melalui program Bina Keluarga Lansia (BKL).

Program BKL yang dilaksanakan oleh BKKBN merupakan wadah kegiatan bagi lansia dan keluarga yang memiliki lansia untuk meningkatkan keterampilan keluarga dalam memberikan pelayanan, perawatan dan pengakuan yang layak sebagai lansia. Program ini juga bertujuan untuk meningkatkan kesejahteraan keluarga lansia melalui kegiatan pemberdayaan, pembinaan, serta pengembangan potensi bagi lansia. Melalui kelompok BKL, lansia akan mendapatkan penyuluhan-penyuluhan dari Kader BKL yang sifatnya selain menambah pengetahuan juga memberikan dorongan, bahkan sebagai konsultan dan mediator.

BKL tersebar di beberapa tempat di daerah DIY. Di Kabupaten Gunungkidul, menurut data dari DP 3 AKBPMD (Dinas Pemberdayaan Perempuan, Perlindungan Anak dan KB, Pemberdayaan Masyarakat dan Desa) Kabupaten Gunungkidul, jumlah kelompok kegiatan BKL per Desember 2015 seluruhnya ada 126 kelompok yang tersebar di 18 kecamatan.

Salah satu BKL yang menjadi subjek pengamatan adalah BKL Kecubung, di Dusun Kerjan, Desa Beji, Kecamatan Patuk, Kabupaten Gunungkidul. Permasalahan yang ada adalah keberadaan penggerak/kader BKL untuk mau dan mampu mengelola BKL masih susah. Hal ini telah menjadi perhatian instansi terkait dengan memberikan solusi melalui berbagai pelatihan terkait lansia bagi para kader
BKL. Selain itu, para lansia anggota BKL belum sepenuhnya merasakan kebermanfaatan secara langsung. BKL masih sedikit dirasakan kebermanfaatannya oleh lansia dan keluarganya.

Berdasarkan banyaknya permasalahan tersebut dan mengingat peran lansia di dalam keluarga sangatlah penting, maka upaya yang dapat dilakukan kader BKL dalam meningkatkan kualitas hidup lansia adalah dengan mewujudkan lansia tangguh dalam 7 dimensi dengan suasana penyuluhan yang kondusif dan komunikatif agar tercipta suasana yang menyenangkan dan mampu mewujudkan tujuan proses penyuluhan tersebut.

Konsep lansia tangguh adalah seseorang atau kelompok lansia yang tetap sehat (secara fisik, sosial, dan mental), mandiri, aktif dan produktif. Lebih lanjut menurut WHO (2002), kata "aktif" berarti penduduk lansia tetap berpartisipasi dalam kegiatan sosial, ekonomi, budaya, spiritual dan kegiatankegiatan kemasyarakatan lainnya dan bukan berarti hanya kemampuan untuk aktif secara fisik serta berpartisipasi dalam angkatan kerja semata. Adapun yang merupakan 7 dimensi lansia tangguh yaitu dimensi spiritual, intelektual, fisik, emosional, sosial kemasyarakatan, profesional vokasional dan lingkungan (BKKBN, 2014:26). Wadah kegiatan untuk mewujudkan lansia tangguh 7 dimensi adalah melalui kelompok BKL. Kegiatan BKL yang dapat dilakukan dengan tujuan meningkatkan pengetahuan dan keterampilan keluarga yang memiliki lansia dan lansia itu sendiri untuk meningkatkan kualitas hidup lansia dalam rangka mewujudkan lansia tangguh.

Berangkat dari permasalahan tersebut, perlu dilakukan penelitian 
mengenai upaya mewujudkan lansia tangguh melalui program Bina Keluarga Lansia di Dusun Kerjan, Desa Beji, Kecamatan Patuk, Kabupaten Gunungkidul.

\section{METODE}

Penelitian ini menggunakan pendekatan deskriptif kualitatif karena mendeskripsikan, menguraikan, dan menggambarkan dalam bentuk kata-kata bukan berkenaan dengan angka-angka tentang pelaksanaan kelompok kegiatan BKL Kecubung.

Penelitian ini dilaksanakan di BKL Kecubung di Dusun Kerjan, Desa Beji, Kecamatan Patuk, Kabupaten Gunungkidul. Adapun waktu penelitian ini dilaksanakan pada bulan April sampai dengan bulan Juni 2017.

Subjek penelitian ini adalah pengelola BKL Kecubung, narasumber penyuluhan, dan anggota kelompok kegiatan BKL Kecubung baik lansia maupun keluarganya. Melalui pengelola BKL akan didapatkan informasi mengenai profil, strategi dan program BKL dalam mewujudkan lansia tangguh. Sedangkan melalui narasumber penyuluhan dan anggota kelompok BKL akan didapatkan informasi mengenai pelaksanaan dan hasil kegiatan BKL.

Adapun di dalam penelitian ini, teknik pengumpulan data yang digunakan adalah observasi, wawancara dan dokumentasi. Observasi dalam penelitian ini dilakukan pada BKL Kecubung dengan mengamati aktivitasaktivitas yang relevan dengan pelaksanaan tujuh dimensi lansia tangguh. Observasi dilakukan dengan melihat aspek kondisi fisik maupun nonfisik. Kondisi fisik berupa sarana dan prasarana kegiatan BKL. Sedangkan kondisi nonfisik meliputi aktivitas pelaksanaan, hasil kegiatan, faktor-faktor pendorong dan penghambatnya.
Wawancara dilakukan dengan pengelola BKL, narasumber kegiatan dan anggota BKL itu sendiri. Selain itu juga dilakukan wawancara untuk mengetahui aktivitas pelaksanaan, peran kader dan keluarga lansia, faktor pendukung dan faktor penghambat serta hasil kegiatan tersebut. Dokumentasi digunakan untuk memperoleh data tambahan yang telah diperoleh melalui teknik observasi dan wawancara. Dokumentasi ini diperoleh dengan mencari informasi melalui foto, hasil karya, materi, arsip, kelengkapan administrasi dan catatan lain yang dapat digunakan untuk mendapatkan informasi tentang pelaksanaan kegiatan BKL dalam mewujudkantujuh dimensi lansia tangguh yang disesuaikan dengan sumber informasi.

Instrumen yang digunakan adalah peneliti sendiri yang dibantu dengan alat bantu berupa pedoman observasi, pedoman wawancara dan dokumentasi untuk mengumpulkan data yang terkait dengan permasalahan yang akan diteliti.

Teknik analisis data dalam penelitian ini adalah teknik analisis kualitatif dengan model analisis yang dikembangkan oleh Milles dan Huberman. Dalam model analisis ini terdapat 3 tahapan yaitu, reduksi data (data reduction), penyajian data (data display), dan penarikan kesimpulan (conclusion drawing/ verification).

\section{HASIL DAN PEMBAHASAN}

\section{Upaya Mewujudkan Lansia}

\section{Tangguh di BKL Kecubung}

$\begin{array}{lrr}\text { Salah satu bentuk upaya } \\ \text { mewujudkan lansia } & \text { tangguh yaitu } \\ \text { melalui kelompok } & \text { kegiatan } & \text { Bina } \\ \text { Keluarga Lansia (BKL). BKL merupakan } \\ \text { kelompok kegiatan keluarga yang } \\ \text { mempunyai lansia bertujuan untuk } \\ \text { meningkatkan pengetahuan dan } \\ \text { keterampilan keluarga yang memiliki }\end{array}$


lansia dan lansia itu sendiri untuk meningkatkan kualitas hidup lansia dalam rangka mewujudkan lansia tangguh. BKL yang menjadi subyek penelitian adalah BKL Kecubung di Dusun Kerjan, Beji, Patuk, Gunungkidul.

a. Perencanaan kegiatan BKL

\section{Kecubung}

Awal perencanaan kelompok kegiatan di BKL Kecubung berlatar belakang karena adanya himbauan dari pemerintah kecamatan setempat untuk membuat kelompok BKL. Namun sebelumnya di Dusun Kerjan juga telah dibentuk kelompok yang serupa dan sudah lama tidak berkegiatan lagi.

Sedangkan upaya pembentukan BKL ini bertujuan untuk meningkatkan kesehatan dan kesejahteraan lansia melalui kegiatan penyuluhan yang diberikan bagi lansia dan juga keluarganya khususnya di wilayah Padukuhan Kerjan, Beji, Patuk, Gunungkidul.

Tujuan pembentukan BKL tersebut agar dapat tercapai dengan baik maka diperlukan perencanaan dan persiapan yang matang dalam menentukan tenaga, sarana, prasarana dan waktu pelaksanaan kegiatannya. Tahap perencanaan dilakukan dengan mengadakan pertemuan yang dihadiri oleh para kader dan Kepala Dusun namun tidak melibatkan para lansia. Dengan tidak ingin mengulangi kesalahan di masa lalu, para kader mengubah susunan kepengurusan di BKL ini. Para kader membuat susunan kepengurusan yang baru dan kemudian susunan kepengurusan BKL Kecubung tersebut disahkan oleh Pemerintah Desa setempat.

Selain membentuk susunan kepengurusan, para kader BKL juga menentukan waktu dan tempat pertemuan BKL. Berdasarkan wawancara dan pengamatan di lapangan, kegiatan BKL Kecubung dilaksanakan sebulan sekali yaitu setiap tanggal 10 dan bertempat di Balai Dusun Kerjan.

Sedangkan untuk mengundang para lansia sebagai sasaran kegiatan BKL Kecubung, para kader membuat undangan pada awal pertemuannya dan mengumumkan di pertemuan arisan rutin Minggu Legi.

b. Pelaksanaan kegiatan BKL

\section{Kecubung}

Kegiatan BKL Kecubung dilaksanakan pada tanggal 10 setiap bulannya namun jika ada alasan lain, tanggal pertemuannya diundur. Selain itu kegiatan BKL Kecubung yang terintegrasi dengan Posyandu Lansia pelaksanaannya juga bersamaan dengan Posyandu Balita.

Berikut ini adalah pelaksanaan kegiatan di BKL Kecubung, yaitu:

1) penyuluhan,

2) cek kesehatan,

3) simpan pinjam,

4) senam lansia,

5) kunjungan rumah,

6) rujukan, dan

7) pencatatan Kartu Lansia.

c. Penilaian kegiatan BKL

\section{Kecubung}

Penilaian kegiatan di BKL Kecubung sebagaimana yang dirangkum peneliti melalui wawancara dan dokumentasi, didapatkan bahwa tidak ada kegiatan penilaian di setiap akhir pertemuan BKL. Baik secara internal oleh pengelola BKL maupun penilaian eksternal oleh lembaga ataupun masyarakat. Namun, kader mengakui bahwa mereka hanya membuat laporan kepada Puskesmas Patuk sebagai mitra mereka di dalam pelayanan kesehatan. Laporan tersebut berkenaan dengan 
jumlah dan kondisi kesehatan lansia di BKL Kecubung.

\section{Peran Kader BKL dan Keluarga Lansia dalam Mewujudkan Lansia Tangguh di BKL Kecubung}

a. Peran kader BKL Kecubung dalam mewujudkan lansia tangguh

1) Peran kader BKL di dalam kegiatan rutin

Peran kader BKL Kecubung yang dilakukan dalam kegiatan rutin BKL setiap tanggal 10 ada beberapa hal. Seorang kader dituntut berperan untuk mewujudkan lansia tangguh yaitu dengan melakukan penyuluhan, memeriksa kesehatan lansia dan memberikan rujukan. Dalam melakukan penyuluhan, kader berpedoman atas ilmu yang diperoleh dari pelatihan yang pernah diikuti sebelumnya. Namun, tidak semua kader pernah mengikuti pelatihan.

Adapun di dalam penyuluhan tersebut, para kader memberikan pemahaman kepada lansia untuk dapat menjaga kesehatan tubuhnya dan memperhatikan pola makan yang baik dan sehat melalui tips-tips kesehatan. Dalam penyuluhan tersebut juga tidak terlepas ketujuh dimensi lansia tangguh. Di dalam dimensi intelektual misalnya, kader memberikan permainan sederhana dengan tebak-tebakan sehingga dapat mengasah kembali kemampuan mengingat lansia.

Kader juga berperan untuk memeriksa atau mengecek kondisi kesehatan lansia. Setelah penyuluhan selesai, para kader akan mempersiapkan diri di meja masing-masing sesuai dengan tugasnya masing-masing. Ada yang bertugas menimbang berat badan lansia, mengukur tekanan darah, mengecek kadar gula, kolesterol, ataupun asam urat. Sehingga sudah dipastikan bahwa kader juga harus memiliki keterampilan untuk menggunakan alat-alat ukur tersebut dan mengidentifikasikan kondisi tubuh lansia. Hasilnya lalu dicatat di dalam Kartu Lansia masing-masing. Sedangkan apabila ada lansia yang membutuhkan pengobatan di Puskesmas karena kondisi tubuhnya tidak sehat, maka kader juga memberikan surat rujukan agar dapat diberikan tindakan yang sesuai.

Selain itu kader juga memiliki peran dalam mengupayakan kemitraan dengan beberapa pihak untuk mengembangkan kegiatan di BKL. Kader BKL Kecubung dalam hal ini pernah bermitra dengan Puskesmas Patuk I untuk memberikan penyuluhan kesehatan ataupun pemeriksaan kesehatan. Dengan adanya mitra yang ahli di bidangnya, kegiatan BKL dapat lebih mengena bagi para lansia. BKL Kecubung juga bekerjasama dengan PLKB (Petugas Lapangan Keluarga Berencana) dari Kecamatan Patuk untuk memberikan penyuluhan juga. Berdasarkan pengamatan dan wawancara, bentuk kerjasama di BKL Kecubung lebih pada partisipasi sebagai narasumber. Sedangkan partisipasi dalam bentuk pendanaan ataupun pengadaan alat bahan penunjang kegiatan belum pernah dilakukan.

\section{2) Peran Kader BKL di luar kegiatan rutin \\ Para kader juga memiliki peranan} di luar kegiatan BKL yaitu memberikan motivasi kepada lansia dan keluarganya. Pemberian motivasi ini bertujuan untuk terus mendorong mereka agar menjaga kesehatan lansia ataupun ikut berkegiatan di BKL. Di luar kegiatan BKL, misalnya di lingkungan daerahnya kader BKL juga dituntut untuk dapat menjaga hubungan baik dengan lansia dengan bersikap ramah dan menghormatinya. Bukan tanpa alasan, 
hal ini dilakukan agar menjaga hubungan yang baik dengan lansia. Tidak hanya ramah di saat pertemuan BKL saja, para kader juga harus ramah dan hormat dimanapun dan kapanpun bertemu dengan lansia ataupun anggota keluarganya. Dengan bersikap ramah ini bertujuan agar lansia merasa nyaman dan dekat dengan para kadernya sehingga tidak segan untuk datang ke pertemuan BKL.

Bentuk keramahan kader itu juga bisa bermacam-macam. Bisa melalui keramahan dalam berbicara kepada lansia, seperti menyapa lansia dan menanyakan kabarnya. Keramahan lainnya juga melalui perbuatan yang dapat ditunjukkan dengan membantu atau mengantarkan lansia apabila berpapasan di jalan.

Kader BKL juga berperan untuk melakukan kunjungan rumah saat lansia ada yang sakit. Kunjungan rumah memang merupakan kegiatan di BKL, akan tetapi agendanya bersifat insidental dilakukan di luar kegiatan rutin BKL apabila ada anggota lansia BKL yang sedang sakit. Kunjungan rumah dilakukan sebagai upaya untuk menunjukkan kepedulian kader terhadap kondisi kesehatan lansia.

b. Peran keluarga lansia dalam mewujudkan lansia tangguh

1) Mengingatkan untuk hidup bersih dan sehat

Selalu menjaga hidup yang bersih dan sehat menjadi kebiasaan penting bagi lansia. Peran keluarga dimulai dari mengingatkan lansia untuk menjaga kebersihan dan kesehatan dirinya. Keluarga akan merasa bahagia apabila lansianya juga dalam kondisi sehat sehingga mereka juga akan leluasa dalam beraktivitas. Hidup bersih dan sehat yang mereka ingatkan adalah dengan menjaga pola makan, memilih makanan yang bersih dan menyehatkan bagi tubuh lansia. Dengan asupan makanan yang baik maka badan akan menjadi sehat dan bugar.

Selain itu lansia juga diingatkan untuk melakukan apa yang telah didapatkan di BKL, seperti senam lansia. Gerakan senam lansia yang sederhana tidak menimbulkan cedera pada lansia, namun dapat membantu lansia melatih anggota tubuhnya bergerak dengan baik. Meski tidak ikut terlibat kegiatan di BKL seperti senam lansia, keluarga mengingatkan agar lansia melakukannya di rumah. Beberapa lansia telah mencoba mengulangi gerakan senam lansia di rumahnya.

Berdasarkan pernyataan di atas dapat disimpulkan bahwa peran keluarga yang pertama untuk membantu mewujudkan lansia yang tangguh adalah dengan senantiasa mengingatkan lansia untuk dapat hidup bersih dan sehat. Dengan peranan ini keluarga juga membantu untuk mewujudkan lansia tangguh dimensi fisiknya.

2) Memberi dorongan untuk tetap mengikuti kegiatankegiatan di luar rumah termasuk pengembangan hobi

Meskipun lansia sudah tidak produktif lagi untuk bekerja, namun keluarga tidak melarang lansia untuk beraktivitas di lingkungan tempat tinggalnya. Lansia di BKL Kecubung tergolong lansia yang masih aktif ikut berkegiatan di dusunnya. Seperti mengikuti kegiatan BKL, Rasulan dan beribadah di tempat ibadahnya.Mereka dibolehkan dan didukung oleh keluarganya, seperti mengantarkan ke tempat kegiatan. Sehingga mereka merasa masih dihargai dan dihormati oleh keluarga dan lingkungannya.

Namun, keluarga juga selektif untuk membolehkan lansianya untuk berkegiatan di luar rumah. Kegiatan tersebut haruslah yang memberikan 
manfaat bagi lansia dan tidak memberatkan kondisi tubuh lansia.

Selain membolehkan lansia berkegiatan di luar rumah, keluarga juga berperan untuk mendukung lansia melakukan hobi atau kegemarannya. Melakukan hobi bagi lansia sangat baik karena dapat memanfaatkan waktunya dengan hal-hal yang ia sukai, sehingga mereka tidak bosan untuk hidup. Ia memiliki kesibukan dengan hobinya tersebut, sehingga apa yang ia lakukan dapat membahagiakannya. Beberapa hobi yang dilakukan oleh lansia di BKL Kecubung adalah yang berkaitan dengan memelihara hewan, seperti kucing dan kambing.

Berdasarkan pernyataan di atas dapat disimpulkan bahwa peran keluarga yang kedua membantu mewujudkan lansia yang tangguh adalah dengan memberikan dorongan kepada lansia untuk tetap mengikuti kegiatan di luar rumah dan juga melakukan hobinya agar dapat menikmati hidupnya dengan bahagia. Dengan peran ini keluarga membantu lansia untuk tangguh di dalam dimensi profesional vokasional, spiritual dan lingkungan.

\section{3) Bersikap sabar terhadap perilaku lansia}

Kesabaran dalam menghadapi lansia juga harus dimiliki oleh anggota keluarga. Lansia di BKL Kecubung hidup mandiri namun tidak menutup kemungkinan apabila mereka mengalami kesulitan dalam mencukupi kebutuhannya. Seorang anak akan merasa bertanggung jawab terhadap kondisi orang tuanya, sehingga mereka akan memperjuangkan berbagai cara agar hidup orang tuanya lebih baik. Namun terkadang perjuangan tidak cukup, dibutuhkan sikap sabar untuk menghadapi perilaku lansia yang sesekali dapat berubah-ubah.
Lansia BKL Kecubung masih aktif berkegiatan, kondisi ini membantu mereka untuk menjaga dan membantu emosinya dengan baik. Mereka terbiasa berkegiatan dan akan bosan apabila anaknya melarangnya untuk diam di rumah. Tak jarang lansia malah tidak mempedulikan nasehat anaknya tersebut dan berkegiatan hingga dapat mencederai mereka.

Namun akan berbeda lagi apabila yang menjadi kendala adalah ketika terjadinya penurunan daya ingat pada lansia. Meski anak telah menasehati atau sekedar mengingatkan ibunya untuk tidak berkegiatan yang melelahkan misalnya, namun apabila sang ibu lupa akan nasehat tersebut maka tidak akan bisa dilakukan. Hal terpenting dari sang anak adalah agar tidak merasa kesal dengan sikap ibu atau orang tuanya dan selalu bersikap sabar. Bersikap sabar, bertutur kata yang lembut dan tidak marah-marah terhadap lansia akan membuat lansia dapat mengatur dan mengelola emosi baiknya sehingga ia juga tidak terpancing untuk mengeluarkan emosi yang buruk.

Berdasarkan pernyataan di atas dapat disimpulkan bahwa peran keluarga yang ketiga untuk membantu mewujudkan lansia yang tangguh adalah senantiasa bersikap sabar menghadapi perilaku lansia yang berubah-ubah. Dengan menjaga kesabaran maka keluarga juga berperan untuk mewujudkan lansia yang tangguh di dalam dimensi emosional.

\section{4) Memberikan kasih sayang, menyediakan waktu dan perhatian yang baik pada lansia \\ Usianya yang telah renta,} membuat lansia lebih memilih kasih sayang anak cucunya daripada pemberian uang dari mereka. Peran keluarga dalam hal ini lebih sebagai 
sahabat lansia yang mampu memberikan perhatian terhadap hal-hal yang baik untuk lansia, mencurahkan kasih sayangnya saat sehat sekalipun dan juga mampu menyediakan waktu sibuknya meski hanya sekedar menemaninya jalan pagi. Di saat lansia sehat, peran keluarga menjadi sahabatnya yang harus bisa melindungi lansia dari gangguan fisik, emosional maupun sosial.sedangkan saat lansia lemah, keluarga harus bisa menjadi sahabatnya yang mampu merawat dengan perhatian dan kasih sayang.

Lansia sangat merasa senang dengan perlakuan sayang dari anak cucunya. Mereka tidak akan merasa kesepian lagi sehingga merasa sangat dipedulikan dan dianggap penting di dalam rumah tangganya. Dengan menyediakan waktu khusus bagi lansia berbicara, bercanda bersama-sama anak cucunya maka akan dapat mengontrol emosi lansia dengan baik.

Bentuk perhatian kepada lansia bisa juga diberikan dengan mengupayakan alat bantu panca indera, seperti membelikan kacamata atau alat bantu dengar. Hal ini dapat memudahkan lansia beraktivitas dan berinteraksi dengan orang lain.

Berdasarkan pernyataan di atas dapat disimpulkan bahwa peran keluarga yang keempat untuk membantu mewujudkan lansia yang tangguh adalah dengan memberikan kasih sayang penuh pada lansia, menyediakan waktu bersama lansia dan memberikan perhatian yang baik padanya.Sehingga lansia dapat menjalani hidup yang baik sebagai lansia yang tangguh di dalam dimensi emosional dan sosial kemasyarakatan.

5) Membantu keuangan lansia

memenuhi

Saat lansia mengalami penurunan kondisi fisiknya, bekerja menjadi satu hal yang tidak lagi bisa ia kerjakan. Lansia yang tidak bekerja menjadi tanggungan bagi keluarganya. Menurut pengamatan di lapangan, lansia di BKL Kecubung bukanlah dari kalangan pensiunan. Mereka banyak bekerja di ladang, berdagang dan berternak. Meski mereka masih berusaha sendiri untuk sebisa kemampuannya menghasilkan uang, namun peran keluarga juga harus mampu untuk membantu memenuhi kebutuhan akan aktualisasi diri lansianya.

Begitu juga dengan anak-anak lainnya yang tidak tinggal bersama lansia. Mereka juga bisa berperan serta meski tidak serumah. Ada lansia yang merasa senang ketika mendapatkan kiriman uang dari anaknya yang tinggal di luar kota. Dengan berperan seperti ini dapat menumbuhkan ketangguhan lansia secara fisik, mental dan juga sosial.

Berdasarkan pernyataan di atas dapat disimpulkan bahwa peran keluarga yang kelima untuk membantu mewujudkan lansia yang tangguh adalah dengan membantu memenuhi keuangan lansia. Meski mereka masih mampu berusaha sendiri, namun dengan uang yang ia miliki dapat mengaktualisasikan dirinya. Sehingga lansia dapat menjalani hidup yang baik sebagai lansia yang tangguh di dalam dimensi profesional vokasional.

\section{6) Membantu mencukupi kebutuhan makanan bagi lansia}

Tidak hanya keuangan saja yang keluarga lansia harus penuhi, namun juga kebutuhan akan makanan yang sehat bagi lansia. Sehingga dengan tercukupinya makanan maka dapat menunjang aktivitas fisiknya dan badan tetap sehat. Kebutuhan makanan bagi lansia juga harus keluarga perhatikan sebab ada beberapa zat makanan yang tidak bisa leluasa dikonsumsi oleh lansia. 


\section{Diklus: Jurnal Pendidikan Luar Sekolah, 2 (3), September 2019 - 147 \\ Bigi Pangestuti}

Seperti makanan yang banyak mengandung lemak jenuh, makanan yang asin atau manis. Sebaiknya lansia lebih banyak mengkonsumsi makanan yang berserat dan yang mengandung lemak nabati.

Keluarga yang tinggal serumah dengan lansia, makanan untuk keluarga tersebut juga harus disesuaikan dengan asupan gizi lansia. Namun di daerah Krajan ini para lansia tidak banyak mengeluhkan dengan makanan yang dihidangkan oleh anaknya.

Berdasarkan pernyataan di atas dapat disimpulkan bahwa peran keluarga yang keenam untuk membantu mewujudkan lansia yang tangguh adalah dengan membantu lansia mencukupi kebutuhan makanannya. Apalagi bagi mereka yang tinggal serumah dengan lansia. Dengan memberikan makanan yang baik dan sehat maka lansia dapat memiliki ketangguhan di dalam dimensi fisik dan juga intelektualnya.

\section{7) Memberikan kesempatan untuk tinggal bersama}

Berdasarkan pengamatan dan wawancara di lapangan, para lansia di dusun Kerjan tinggal serumah bersama anak cucunya. Ada juga yang tidak tinggal serumah, akan tetapi rumah lansia dengan rumah anaknya berdekatan. Seperti kebanyakan tradisi di pedesaan bahwa anak yang bungsu akan menjadi penghuni rumah orang tuanya selama-lamanya. Sehingga anak bungsu adalah teman hidup yang akan merawat orang tuanya hingga meninggal. Begitu juga yang terjadi di masyarakat dusun Kerjan ini. Tidak dipungkiri lagi bahwa mereka para lansia dapat hidup dengan bahagia bersama keluarganya.

Berdasarkan pernyataan di atas dapat disimpulkan bahwa peran keluarga yang ketujuh untuk membantu mewujudkan lansia yang tangguh adalah dengan memberikan kesempatan untuk tinggal bersama lansia. Sehingga lansia tidak merasa kesepian hidupnya. Dengan cara ini dapat membantu mewujudkan lansia yang tangguh di dalam dimensi sosial kemasyarakatan dan emosional.

Membantu dalam hal
transportasi
Keluarga juga berperan untuk membantu dalam transportasi bagi lansia. Apabila lansia hendak pergi ke luar rumah misalnya menghadiri BKL ataupun kegiatan aktualisasi diri lainnya maka peran keluarga dibutuhkan. Kondisi jalan di dusun Kerjan yang naik turun karena berada di perbukitan memang menyulitkan lansia untuk berjalan kaki apabila hendak bepergian sendiri. Oleh karenanya keluarga membantu lansia agar mudah bepergian seperti dengan mengantarkannya ke lokasi kegiatan.

Berdasarkan pernyataan di atas dapat disimpulkan bahwa peran keluarga yang kedelapan untuk membantu mewujudkan lansia yang tangguh adalah dengan membantu dalam hal transportasi bagi lansia. Dengan kemudahan transportasi tersebut lansia dapat leluasa bepergian dan mengaktualisasikan dirinya. Sehingga mampu menjadi lansia yang tangguh pada dimensi profesional vokasionalnya dan juga sosial kemasyarakatan.

\section{9) Mencegah terjadinya \\ kecelakaan di dalam maupun di luar rumah}

Keluarga tidak hanya sekedar memberikan kesempatan untuk tinggal bersama lansia saja, namun keluarga juga harus membuat tempat tinggal yang aman bagi lansia. Apalagi jika lansia tersebut memiliki kecacatan. Tempat tinggal yang aman bagi lansia berarti meminimalisir resiko bahaya yang dapat lansia derita, seperti terjatuh, terpeleset ataupun tersengat listrik. Berdasarkan 
pengamatan di lapangan, lantai rumah mereka terbuat dari tanah, sehingga resiko terpeleset lebih kecil.

Selain memfasilitasi rumah yang aman bagi lansia, keluarga juga berupaya untuk membatasi aktivitas lansia sehariharinya, misalnya dengan melarang untuk berdagang di pasar yang cukup jauh ataupun membatasi kegiatan lansia di rumah yang dapat mencederai mereka. Cara lain juga dengan menyediakan perlengkapan pertolongan pertama di rumah apabila lansia sewaktu-waktu mengalami cedera.

Namun, ada juga lansia yang tidak mematuhi apa yang anak mereka katakan. Lansia di Dusun Kerjan tergolong masih aktif berkegiatan di luar rumah mereka, seperti sekedar mencari pakan untuk ternak mereka. Sehingga apabila hal itu tidak mereka lakukan, hanya akan membuat kebosanan.

Lansia di pedesaan tergolong masih aktif berkegiatan sehingga keluarga dapat memakluminya. Adapun untuk mencegah mereka mengalami kecelakaan adalah senantiasa mengingatkan agar berhati-hati dan mengawasi lansia dalam kegiatan. Menyediakan kotak pertolongan pertama juga menjadi hal yang harus dimiliki oleh keluarga. Berdasarkan pernyataan di atas dapat disimpulkan bahwa peran keluarga yang kesembilan untuk membantu mewujudkan lansia yang tangguh adalah dengan mencegah terjadinya kecelakaan di dalam maupun di luar rumah dengan cara mencegah mereka untuk beraktivitas yang dapat mencederai tubuh mereka. Lansia juga perlu untuk diingatkan sebelum beraktivitas agar lebih berhati-hati. Keluarga juga perlu menyiapkan kotak pertolongan pertama di rumah jika kecelakaan sewaktu-waktu terjadi.
3.

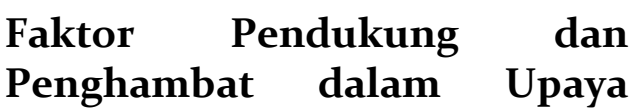

\section{Mewujudkan Lansia Tangguh di BKL Kecubung}

a. Faktor pendukung dalam upaya mewujudkan lansia tangguh di BKL Kecubung

Kegiatan BKL Kecubung dari awal hingga kini telah berjalan dengan baik untuk terus mengupayakan terwujudnya lansia yang tangguh tak lepas dari beberapa faktor pendukung. Berdasarkan hasil wawancara dan pengamatan yang dilakukan oleh peneliti dengan para pengelola BKL, anggota BKL, keluarga dan narasumber terdapat beberapa faktor pendukung dalam pelaksanaan kegiatan di BKL Kecubung, yaitu sebagai berikut.

\section{1) Adanya semangat dari para lansia untuk hadir di BKL}

Para lansia di Dusun Kerjan sangat bersemangat untuk ikut serta dalam kegiatan di BKL Kecubung. Meski pertemuan rutin hanya sekali sebulan, mereka mengaku senang untuk hadir di BKL karena dapat berkumpul bersama dengan lansia lainnya.

Bahkan ada beberapa lansia yang menginginkan untuk ditambah pertemuan BKLnya seperti senam lansia karena mereka sangat senang mengikutinya. Sebelum berangkat ke pertemuan BKL pun, mereka mencari rumput atau dedaunan untuk makanan ternak kambingnya terlebih dahulu. Meski mereka punya kewajiban lain akan tetapi datang ke BKL Kecubung tetap mereka upayakan.

Berdasarkan berbagai pendapat di atas dapat disimpulkan bahwa faktor pendukung dalam upaya mewujudkan lansia tangguh di BKL Kecubung adalah adanya semangat dari para lansia anggota BKL untuk hadir dalam kegiatan di BKL Kecubung.Mereka selalu mengupayakan hadir di BKL namun sebelumnya juga menyempatkan untuk menyelesaikan tugas-tugasnya dahulu, 
seperti mencari pakan ternak. Bahkan ada beberapa lansia yang menginginkan pertemuan senam ditambah karena senang mengikutinya.

2) Para kader yang berperan aktif

\section{dan ramah}

Keaktifan kader di BKL Kecubung merupakan salah satu yang mendukung kegiatan BKL. Mereka menjadi penggerak keberhasilan kegiatan di BKL Kecubung. Selain itu jumlah kadernya yang banyak dan saling mendukung tugas satu sama lainnya.

Meski menjadi kader itu tidak mudah dan ada kalanya mengalami berbagai kendala, namun mereka dapat bertugas sebagaimana mestinya.

Keaktifan para kader menjadi hal penting bagi suatu organisasi agar bisa diterima oleh masyarakat. Para kader yang aktif dan juga ramah dalam memberikan pelayanan kepada lansia mendapat respon yang positif dari masyarakat dan instansi lainnya.

Berdasarkan pernyataan di atas dapat disimpulkan bahwa faktor pendukung dalam upaya mewujudkan lansia yang tangguh yang kedua karena kader yang berperan aktif dalam kegiatan BKL dan bersikap ramah terhadap lansia. Kader di BKL Kecubung sangat banyak dan aktif berkegiatan. Mereka juga terkesan ramah dengan lansia di dalam maupun luar kegiatan BKL. Mereka saling membantu dan bekerjasama menjalankan perannya.

\section{3) Adanya kepercayaan dari pemerintah desa dan kecamatan}

Peran pemerintah desa Beji dan juga pemerintah kecamatan Patuk sangat baik membantu terselenggaranya kegiatan di BKL Kecubung ini. Sebagai instansi pemerintahan yang terdekat dengan BKL, mereka memberikan kepercayaan kepada kader di dusun
Kerjan ini untuk mengelola BKL. Peran mereka meliputi menginisiasi berdirinya BKL, memberikan izin pengelolaan kegiatan BKL dan juga memberikan arahan untuk kegiatan BKL yang lebih baik lagi.

Berdasarkan pernyataan di atas dapat disimpulkan bahwa faktor pendukung dalam upaya mewujudkan lansia yang tangguh yang ketiga karena adanya kepercayaan dari pemerintah desa dan kecamatan untuk para kader mengelola BKL Kecubung dengan baik

\section{4) Dukungan mitra dan dinas terkait}

Peran mitra dan dinas terkait seperti pihak Puskesmas Patuk, BKKBN, $\mathrm{DP}_{3} \mathrm{AKBPMD}$ dan instansi pemerintah tingkat desa dan kecamatan sangat berpengaruh pada perkembangan BKL Kecubung. Sejak awal berdiri hingga dilaksanakan sampai sekarang, BKL Kecubung telah menerima banyak masukan dan dukungan dari berbagai pihak. Dinas Perlindungan dan Pemberdayaan Perempuan dan Anak Keluarga Berencana Pemberdayaan Masyarakat Desa (DP3AKBPMD) Gunungkidul senantiasa memberikan bekal bagi para kader agar mampu meningkatkan kapasitas BKL melalui program-program pelatihan yang diberikan.

Selain mendapat dukungan dari dinas terkait, BKL Kecubung juga tidak lepas dari dukungan mitra kerja yang membantu dalam pelaksanaan kegiatan pelayanan. Mitra kerja tersebut adalah yang berkaitan dengan pelaksanaan kegiatan layanan.

Dari pendapat di atas dapat disimpulkan bahwa dinas dan mitra kerja memegang peranan yang cukup penting dalam mendukung keberhasilan kegiatan di BKL Kecubung ini. Setiap dinas atau mitra kerja yang bekerja sama dengan 
BKL Kecubung memiliki kontribusi yang berbeda-beda, baik itu berkontribusi di dalam ide maupun keahliannya.

\section{b. Faktor penghambat dalam upaya mewujudkan lansia tangguh di BKL Kecubung}

Adapun kegiatan di BKL Kecubung tidak selamanya berjalan sesuai dengan yang diharapkan oleh para pengelola maupun anggotanya. Beberapa hambatan terjadi seiring dengan pelaksanaan kegiatan di BKL.Faktor penghambat pelaksanaan kegiatan di BKL Kecubung di antaranya dapat diuraikan sebagai berikut.

\section{1) Keterbatasan sarana dan prasarana}

Sarana dan prasarana merupakan salah satu hal yang diperlukan untuk menunjang keberhasilan suatu kegiatan. Keberadaan sarana dan prasarana mampu dimanfaatkan sebagai alat dan penunjang untuk mencapai tujuan. Penggunaan Balai Dusun Kerjan sebagai tempat kegiatan BKL membuat pelaksanaan kegiatan belum memadai. Menurut pengamatan di lapangan, balai dusun ini memang menjadi pusat kegiatan masyarakat di dusun Kerjan, tidak hanya kegiatan BKL saja. Adapun inventaris BKL Kecubung tidak disimpan di tempat ini namun dibawa pulang oleh kader. Balai Dusun Kerjan ini terdiri dari aula pertemuan yang terbuka dan ruangan tempat menyimpan meja dan kursi yang lebih tepatnya sebagai gudang. Di luar bangunan juga terdapat sumur dan kamar mandi namun fasilitasnya belum cukup memadai.

Berdasarkan berbagai pernyataan di atas dapat disimpulkan bahwa faktor yang menghambat kegiatan BKL untuk mewujudkan lansia yang tangguh adalah keterbatasan dari sarana dan prasarana yang dimiliki. Terbatasnya sarana membuat kegiatan penyuluhan di BKL belum optimal, para narasumber juga kesulitan menyampaikan materi dengan peralatan mereka. Namun dari BKL Kecubung sendiri telah mengupayakan ke depannya untuk memindahkan tempat kegiatan BKL yang khusus.

\section{2) Kondisi fisik lansia yang melemah}

Fisik lansia yang sudah cenderung mengalami penurunan menjadi hal yang wajar dan patut dimaklumi oleh semua masyarakat. Hal ini juga yang menjadi hambatan hadirnya lansia untuk ikut serta di kegiatan BKL. Beberapa lansia anggota BKL mengeluhkan badannya yang sakit menjadi alasan mereka tidak hadir di kegiatan BKL.

Namun tidak hanya sakit, penurunan fungsi alat indera juga mempengaruhi lansia mengikuti BKL dengan optimal. Ada lansia yang lain mengeluh bahwa ia kesulitan mendengarkan. Padahal dengan alat indera manusia dapat menerima pesan atau berkomunikasi dengan baik. Meskipun kader BKL telah memberikan penyuluhan yang maksimal atau bahkan dihadirkan narasumber hebat, akan tetapi jika dalam diri lansia ada indera yang kurang bisa menerima dengan baik, maka ini juga akan menjadi penghambatnya. Kepedulian keluarga untuk membantu lansia menyelesaikan hambatan ini juga sudah ditampakkan di BKL ini.

Berdasarkan berbagai pernyataan di atas dapat disimpulkan bahwa faktor yang menghambat kegiatan BKL untuk mewujudkan lansia yang tangguh adalah kondisi fisik lansia yang semakin melemah menuntun mereka untuk beristirahat sejenak di rumah. Selain itu juga fungsi panca indera lansia yang mengalami penurunan juga mempengaruhi pesan-pesan yang mereka terima dari para kader. Namun dari pihak keluarga telah mengupayakan 
alat bantu untuk mengoptimalkan fungsi panca indera lansia.

\section{3) Keterbatasan dalam pendanaan untuk operasional kegiatan BKL}

Pendanaan menjadi faktor penting dalam menjalankan suatu kegiatan agar tercapai sesuai dengan tujuan, namun apabila pendanaan yang dimiliki oleh kegiatan tersebut terbatas maka keberhasilan dalam mencapai tujuan pun tidak dapat optimal. BKL Kecubung juga mengalami hal tersebut. Para kader kesulitan untuk mendanai kegiatan sehingga mereka juga harus pintar untuk mengumpulkan dana. Operasional kegiatan tersebut digunakan untuk pengadaan PMT dan pembelian alat cek kesehatan.

Berdasarkan berbagai pernyataan di atas dapat disimpulkan bahwa faktor yang menghambat kegiatan BKL untuk mewujudkan lansia yang tangguh adalah keterbatasan pendanaan untuk operasional BKL Kecubung. Meski kegiatan BKL tidak sebesar unit kegiatan lain yang lebih besar, namun dana juga sangat diperlukan. Apalagi sumber pendanaan mereka hanya berasal dari anggotanya. Para kader telah mengupayakan berbagai cara agar BKL memiliki dana yang banyak untuk menunjang kegiatannya.

Kondisi geografi rang
menyulitkan lansia untuk
hadir seperti jalan yang
menanjak dan keramaian lalu
lintas
Wilayah Dusun Kerjan terdiri dari
enam RT yang mana terdapat jalan raya membelah wilayah ini. Jalan raya tersebut merupakan jalan utama yang diakses dari kota Wonosari menuju ke kota Yogyakarta. Sehingga sudah pasti jalan tersebut ramai dan banyak dilalui oleh kendaranaan berbagai macam. Untuk hadir ke Balai Dusun yang terletak di selatan jalan raya, para lansia yang tinggal di wilayah utara jalan raya maka mau tidak mau harus menyeberangi keramaian jalan tersebut. Apalagi tidak ada traffic light yang dapat membantu menyeberangkan jalan. Ditambah lagi dengan kondisi jalan dusun yang berada di perbukitan, jalannya tidak datar sehingga menjadi hambatan lansia jalan kaki.

Berdasarkan berbagai pernyataan di atas dapat disimpulkan bahwa faktor yang menghambat kegiatan BKL untuk mewujudkan lansia yang tangguh adalah kondisi geografis Dusun Kerjan yang jalannya naik turun dan ramainya jalan raya di dekatnya. Fisik lansia yang mengalami penurunan sangat sulit apabila berjalan di jalanan tersebut. Namun kader dan keluarga telah mengupayakan agar membantu lansia dapat hadir di BKL.

5) Kurangnya partisipasi dari
keluarga lansia
Faktor keberhasilan BKL juga ditentukan oleh partisipasi dari keluarga lansia untuk ikut serta menyukseskan program lansia tangguh ini. Namun hal ini juga menjadi PR besar bagi para kader BKL, yang tidak hanya di BKL Kecubung saja, para kader BKL lainnya, bahwa PR mereka adalah menjadikan para keluarga lansia hadir ikut serta bersama lansianya di BKL. Karena BKL bukan untuk pertemuan mereka yang sudah tua renta saja, namun BKL menjadi sarana untuk mengedukasi keluarga sebagai pembina lansia dalam rumah tangganya. Jadi, bukan hanya menyerahkan sepenuhnya saja kepada para kader BKL.

Keluarga yang memiliki lansia menjadi anggota BKL Kecubung belum bisa hadir di kegiatan BKL karena kesibukan pekerjaan mereka. Anak atau menantu lansia sudah cukup senang melihat orang tuanya dapat hadir di 
BKL.Namun, ada satu dua juga anak yang mau mengantarkan ke BKL.

Berdasarkan berbagai pernyataan di atas dapat disimpulkan bahwa faktor yang menghambat kegiatan BKL untuk mewujudkan lansia yang tangguh adalah kurangnya partisipasi dari keluarga lansia untuk hadir di kegiatan BKL. Alasannya karena mereka sibuk dengan pekerjaannya. Padahal sejatinya keluarga juga memiliki peranan penting sebagai sahabat lansia. Hanya ada sebagian kecil keluarga yang mau mengantarkan dan ikut serta berkegiatan di BKL.

4. Hasil Kegiatan Lansia Tangguh di BKL Kecubung Dusun Kerjan, Beji, Patuk, Gunungkidul

Hasil dari penerapan kegiatan lansia tangguh di BKL diupayakan untuk mewujudkan lansia yang tetap sehat secara fisik, sosial dan mental, mandiri, aktif dan produktif. Hasil tersebut dapat diukur dengan indikator 7 dimensi lansia tangguh, yaitu dimensi spiritual, intelektual, fisik, emosional, sosial kemasyarakatan, profesional vokasional, dan lingkungan. Adapun hasil penerapan kegiatan lansia tangguh di BKL Kecubung dijelaskan sebagai berikut.

a. Munculnya kebiasan positif yang berkaitan dengan peningkatan nilai spiritual

Diberikan umur yang panjang adalah nikmat dari Sang Maha Esa.Para lansia didorong untuk mensyukurinya dengan beribadah ataupun kegiatan keagamaan lainnya. Sehingga muncullah kebiasaan-kebiasaan positif yang dilakukan lansia yang mendorong mereka untuk bersyukur kepada Tuhan Yang Maha Esa dan meningkatkan spiritualnya untuk menghadapi kematian. Hal ini juga dilakukan oleh lansia di BKL Kecubung, mengisi aktivitas sehari-harinya dengan menyempatkan beribadah di masjid ataupun ikut serta menengok tetangganya yang sakit. Bahkan para lansia juga berangkat melayat apabila ada tetangga yang meninggal dunia.

Dengan munculnya kebiasaankebiasaan positif tersebut mengindikasikan bahwa kegiatan di BKL Kecubung telah membuahkan hasil mampu mewujudkan anggotanya sebagai lansia tangguh dimensi spiritual.

\section{b. Memiliki kegiatan untuk mengasah daya ingatnya}

Dari segi kemampuan psikologis, berpikir dan daya ingat usia lanjut akan mengalami penurunan. Kader BKL Kecubung telah mengupayakan lansia untuk menjadikan mereka sosok yang percaya diri dan mandiri. Melalui kegiatan senam lansia inilah berguna untuk membantu upaya tersebut. Hasilnya dengan adanya senam lansia tersebut, para lansia dapat melakukannya di rumah masing-masing. Dengan begitu lansia dapat mengasah daya ingatnya melalui gerakan-gerakan senam tersebut, meski tidak seperti yang para kader mereka contohkan.

Selain kegiatan itu, mengasah dan meningkatkan kemampuan dan pengetahuan lansia juga ditunjukkan dengan membaca tulisan singkat ataupun bercerita tentang masa lalunya kepada anak cucunya. Lansia dapat mengingat kembali peristiwa dan tempat-tempat yang dulu pernah ia alami. Seperti halnya dengan menonton televisi bersama keluarga juga menambah kegiatan positif lansia untuk mengasah kemampuan daya ingatnya.

Berdasarkan pernyataan di atas dapat disimpulkan bahwa hasil kegiatan di BKL Kecubung adalah para lansia memiliki kegiatan-kegiatan yang dapat mengasah daya ingatnya, melalui senam lansia, membaca, bercerita dan menonton televisi. Hal ini menjadi indikasi bahwa kegiatan di BKL 
Kecubung telah mampu mewujudkan lansia yang tangguh pada dimensi intelektual. Sehingga lansia dapat menikmati hidupnya dengan kebahagiaan, percaya diri dan merasa berguna bagi keluarga maupun masyarakat.

\section{c. Munculnya kebiasaan yang menyehatkan fisik lansia}

Hasil yang sangat dirasakan oleh para lansia dan keluarga mereka adalah dapat merasakan tubuh yang sehat dan bugar. Hal ini tak lepas dari peran para kader BKL dalam memberikan penyuluhan bagi lansia untuk menjaga pola makannya yang sehat. Seperti mengurangi makanan yang banyak mengandung lemak jenuh, terlalu manis atau terlalu asin. Selain menjaga makanan yang sehat, para lansia juga melakukan senam lansia di rumah. Munculnya kebiasaan positif ini sangat baik untuk fisik mereka. Hanya tinggal peran keluarga saja agar terus mendorong lansia hidup sehat dan aktif melalui penyediaan makanan yang sehat.

Para lansia juga menyadari bahwa kondisi fisik mereka mengalami penurunan. Dengan mengikuti BKL mereka juga menjadi tahu kondisi tubuhnya seperti berat badannya atau kadar asam uratnya. Sehingga mereka tetap berupaya untuk menjaga kesehatan tubuhnya. Karena mereka senang apabila diberikan tubuh yang sehat. Dengan tubuh yang sehat dan perasaan senang mereka bisa beraktivitas sendiri sesuka mereka, seperti berdagang ataupun beternak. Bisa juga mengikuti kegiatankegiatan di masyarakat, tanpa harus merepotkan orang lain.

Berdasarkan pernyataan di atas dapat disimpulkan bahwa hasil kegiatan di BKL Kecubung adalah munculnya kebiasaan-kebiasaan positif yang dilakukan lansia yang mendorong mereka untuk hidup sehat dan aktif.
Para lansia dapat melakukan senam lansia sendiri di rumah mereka. Selain itu mereka juga menjaga makanan yang sehat bagi tubuhnya. Dengan dapat merasakan tubuh yang sehat dan bugar, mereka dapat melakukan aktivitas sendiri tanpa harus merepotkan orang lain. Hal ini mengindikasikan bahwa hasil kegiatan BKL Kecubung mampu mewujudkan lansia tangguh dimensi fisik.

\section{d. Adanya harapan untuk menikmati usia tua dengan kemandiriannya}

Hobi, keterampilan dan pekerjaan semuanya dimiliki oleh lansia di BKL Kecubung untuk menikmati usia tuanya. Ketiganya menjadi sebuah paket lengkap bagi lansia untuk mengisi kegiatan hariannya. Ada lansia yang hobi memelihara kucing, ada juga yang memelihara kambing. Ada juga yang masih aktif bekerja dengan berdagang di pasar. Mereka tidak terbebani untuk bekerja keras mengumpulkan banyak uang. Pekerjaan rumah juga masih bisa mereka lakukan sendiri, seperti hanya sekedar menyapu halaman.

Mereka menjadi lansia yang mandiri mampu mencukupi kebutuhannya sendiri. Dengan berbekal badan yang sehat dan keterampilan ataupun minat yang mereka miliki, lansia dapat hidup dengan tidak menggantungkan diri sepenuhnya kepada orang lain. Selain itu mereka juga bisa menikmati hari tuanya dengan hati bahagia dan merasa berguna bagi keluarga dan masyarakat.

Berdasarkan pernyataan di atas dapat disimpulkan bahwa hasil kegiatan lansia tangguh di BKL Kecubung adalah adanya harapan lansia untuk menikmati usia tuanya dengan kemandirian. Mandiri dalam beraktivitas maupun mandiri finansial. Mereka memiliki hobi, pekerjaan dan keterampilan yang dapat 
digunakan untuk mengisi kesehariannya. Dengan begitu lansia menjadi hidup bahagia dan merasa berguna bagi keluarga ataupun masyarakat. Hal ini mengindikasikan bahwa kegiatan BKL Kecubung mampu mewujudkan lansia tangguh dalam dimensi profesional vokasional.

\section{e. Terjalin hubungan yang baik dengan keluarga dan masyarakat}

Hubungan yang baik antara lansia dengan keluarganya ditunjukkan oleh adanya rasa kepedulian dan kasih sayang di antara mereka. Lansia menjadi semakin akrab dengan anak dan cucunya.Ada waktu yang digunakan untuk berkumpul bersama. Dengan hubungan dan kedekatan seperti ini lansia dapat memenuhi kebutuhan akan rasa aman dan kasih sayang dari keluarganya.

Hubungan sosial yang baik terjalin di dalam keluarga. Lansia menjadi lebih bersemangat untuk menjalani harinya. Sehingga timbul rasa senang, berguna bagi keluarga dan kepercayaan diri lansia meningkat. Hal ini juga mengindikasikan secara emosional lansia mampu mengelolanya dengan baik.

Adapun di lingkungan rumahnya, lansia juga masih tetap beraktivitas dan produktif seperti beternak kambing, berkebun dan berjualan di pasar. Lingkungan sekitarnya juga mendukung aktivitas mereka. Sedangkan di lingkungan masyarakatnya, lansia masih dapat terlibat dalam hubungan sosial melalui beragam kegiatan. Dengan keikutsertaannya tersebut menjadikan sarana untuk berbagi dan aktualisasi diri.

Kebutuhan emosi lansia dapat dikelola dengan baik dengan ikut berkegiatan di masyarakat seperti menengok orang sakit, takziyah dan Gejlok Lesung. Dengan ikut kegiatan sosial tersebut, lingkungan masyarakatnya juga mampu menerima keberadaan lansia dengan baik.

Berdasarkan pernyataan di atas dapat disimpulkan bahwa hasil dari kegiatan lansia tangguh di BKL Kecubung yaitu terjalinnya hubungan yang baik antara lansia dengan keluarga dan juga masyarakat. Hubungan tersebut ditunjukkan melalui kegiatan bersama, rasa kepedulian dan kedekatan di antara mereka. Hal ini menunjukkan bahwa kegiatan BKL Kecubung mampu mewujudkan lansia yang tangguh pada dimensi emosional, sosial kemasyarakatan dan lingkungan.

Namun, berbagai hasil tersebut barulah yang diperoleh dari sisi lansia saja karena yang hadir di BKL hanya lansia. Akan lebih baik lagi jika dari sisi keluarga juga merasakan hasilnya dengan ikut hadir di BKL. Karena keluarga juga sasaran BKL dan faktor pendukung keberhasilan program di BKL.

\section{SIMPULAN}

Berdasarkan hasil penelitian dan pembahasan yang telah dilakukan, maka dapat disimpulkan beberapa hal sebagai berikut.

Upaya Mewujudkan Lansia
Tangguh di BKL Kecubung
a. Perencanaan kegiatan BKL
Kecubung
Perencanaan kegiatan di BKL Kecubung pada awalnya dilakukan oleh Kepala Dusun dan para kader. Mereka berembug untuk menentukan susunan kepengurusan BKL Kecubung yang baru, waktu dan tempat pelaksanaan kegiatan BKL. Selanjutnya susunan kepengurusan yang telah selesai dibuat disahkan oleh Pemerintah Desa setempat. Adapun berdasarkan kesepakatan mereka, waktu pelaksanaan kegiatan BKL adalah setiap tanggal 10 yang bertempat di Balai Dusun Kerjan. Sedangkan untuk 
mendatangkan para lansia pada permulaannya, para kader yang mengundang mereka dan mengumumkan di pertemuan arisan rutin Minggu Legi.

\section{b. Pelaksanaan kegiatan BKL Kecubung \\ Pelaksanaan kegiatan di BKL} Kecubung dilaksanakan pada tanggal 10 setiap bulannya namun apabila ada alasan lain, maka tanggal pertemuannya akan diundur. Adapun kegiatan BKL terintegrasi dengan kegiatan Posyandu Lansia yang pelaksanaannya juga bersamaan dengan kegiatan Posyandu Balita. Hal ini dilakukan karena dengan digabungnya kegiatan ini maka dapat berjalan dengan baik. Begitu juga dengan tugas kader juga sama antara kader lansia dan balita.

Pelaksanaan kegiatan di BKL Kecubung terdiri dari beberapa macam yaitu kegiatan penyuluhan, cek kesehatan, simpan pinjam, senam lansia, kunjungan rumah, rujukan, dan pencatatan di dalam Kartu Lansia.

\section{c. Penilaian kegiatan BKL Kecubung}

Penilaian kegiatan di BKL Kecubung belum dilakukan di setiap akhir kegiatannya. Baik penilaian oleh pihak internal maupun oleh pihak eskternal seperti instansi ataupun masyarakat. Namun, BKL Kecubung telah membuat laporan kepada Puskesmas Patuk yang berguna untuk mengetahui jumlah dan kondisi fisik lansia binaanya.

\section{Peran Kader BKL dan Keluarga Lansia Dalam Mewujudkan Lansia Tangguh di BKL Kecubung}

a. Peran kader BKL Kecubung dalam mewujudkan lansia tangguh

Peran kader BKL di dalam kegiatan rutin adalah mengupayakan melakukan penyuluhan kesehatan, melakukan pemeriksaan kesehatan sederhana, memberikan surat rujukan ke Puskesmas terdekat dan mengupayakan kemitraan dengan pihak lain untuk mengembangkan program kegiatan di BKL Kecubung.

Sedangkan peran kader BKL di luar kegiatan rutin adalah memberikan motivasi kepada lansia dan keluarganya, menjaga hubungan baik dengan lansia dan melakukan kunjungan rumah.

b. Peran keluarga lansia dalam mewujudkan lansia tangguh

Selain pentingnya peran dari kader BKL, keluarga lansia juga memiliki peranan yang tidak kalah pentingnya juga dalam upaya mewujudkan lansia tangguh. Peran keluarga tersebut adalah (1) senantiasa mengingatkan lansia untuk dapat hidup bersih dan sehat, (2) memberikan dorongan kepada lansia untuk tetap mengikuti kegiatan di luar rumah dan juga melakukan hobinya, (3) senantiasa bersikap sabar menghadapi perilaku lansia, (4) memberikan kasih sayang penuh pada lansia, menyediakan waktu bersama lansia dan memberikan perhatian yang baik, (5) membantu memenuhi keuangan lansia, membantu lansia mencukupi kebutuhan makanannya, (7) memberikan kesempatan untuk tinggal bersama, (8) membantu dalam hal transportasi bagi lansia, dan (9) mencegah terjadinya kecelakaan di dalam maupun di luar rumah.

Faktor Pendukung dan
Penghambat Dalam Upaya
Mewujudkan Lansia Tangguh di
BKL Kecubung

a. Faktor pendukung dalam upaya mewujudkan lansia tangguh di BKL Kecubung

Beberapa faktor pendukung dalam pelaksanaan kegiatan di BKL Kecubung yaituadanya semangat dari para lansia 
untuk hadir di BKL, para kader yang berperan aktif dan ramah, adanya kepercayaan dari pemerintah desa dan kecamatan, serta dukungan dari mitra dan dinas terkait.

\section{b. Faktor penghambat dalam upaya mewujudkan lansia tangguh di BKL Kecubung \\ Beberapa faktor penghambat dalam} pelaksanaan kegiatan di BKL Kecubung yaitu keterbatasan sarana dan prasarana, kondisi fisik lansia yang melemah, keterbatasan dalam pendanaan untuk operasional kegiatan BKL, kondisi geografis yang menyulitkan lansia untuk hadir seperti jalanan yang menanjak dan keramaian lalu lintas serta kurangnya partisipasi dar keluarga lansia.

\section{Hasil Kegiatan Lansia Tangguh} di BKL Kecubung Dusun Kerjan, Beji, Patuk, Gunungkidul

Hasil dari penerapan kegiatan lansia tangguh di BKL diupayakan untuk mewujudkan lansia yang tetap sehat secara fisik, sosial dan mental, mandiri, aktif dan produktif. Hasil tersebut dapat diukur dengan indikator 7 dimensi lansia tangguh, yaitu dimensi spiritual, intelektual, fisik, emosional, sosial kemasyarakatan, profesional vokasional, dan lingkungan. Adapun hasil penerapan kegiatan lansia tangguh di BKL Kecubung yaitu (1) munculnya kebiasaan positif yang berkaitan dengan peningkatan nilai spiritual, (2) lansia memiliki kegiatan untuk mengasah daya ingatnya, (3) munculnya kebiasaan yang menyehatkan bagi fisik lansia, (4) adanya harapan untuk menikmati usia tuanya dengan kemandirian, serta terjalin hubungan yang baik antara lansia dengan keluarga dan masyarakat.

Saran

Setelah dilakukannya penelitian terhadap upaya untuk mewujudkan lansia yang tangguh di BKL Kecubung di Dusun Kerjan, Beji, Patuk, Gunungkidul maka peneliti memberikan saran yaitu akan lebih baik lagi jika dari sisi keluarga juga ikut hadir di BKL. Karena keluarga juga sasaran BKL dan faktor pendukung keberhasilan program di BKL.

\section{DAFTAR PUSTAKA}

Arikunto, Suharsimi. (2010). Prosedur Penelitian: Suatu Pendekatan Praktik. Yogyakarta: Rineka Cipta.

Badan Kependudukan dan Keluarga Berencana Nasional. (2014). Lansia Tangguh Dengan Tujuh Dimensi. Jakarta: BKKBN.

Badan Kependudukan dan Keluarga Berencana Nasional. (2014). Kebijakan Pembangunan Keluarga. Yogyakarta: BPPM DIY.

Badan Kependudukan dan Keluarga Berencana Nasional. (2014). Lansia Tangguh dengan Tujuh Dimensi. Jakarta: BKKBN.

Badan Pusat Statistik. (2013). Proyeksi Penduduk Indonesia 2010-2035. Jakarta: BPS.

Bandiyah, Siti. (2009). Lanjut Usia dan Keperawatan Gerontik. Yogyakarta: Nuha Medika.

Demartoto, Argyo. (2007). Pelayanan Sosial Non Panti Bagi Lansia. Surakarta: UNS Press.

Dirjen Pelayanan dan Rehabilitasi Sosial Lanjut Usia. (2002). Keputusan Dirjen Pelayanan dan Rehabilitasi Sosial Lanjut Usia tentang Perlindungan Sosial dan Aksesbilitas Lanjut Usia.

Hardiati, Eni. (2008). Faktor-Faktor Kebertahanan Lanjut Usia Perempuan dalam Kegiatan Kerja Ekonomi Produktif di Kota Yogyakarta. Yogyakarta: Depsos $\mathrm{RI} \mathrm{B}_{2} \mathrm{P}_{3} \mathrm{KS}$.

Izzaty, Rita Eka, dkk. (2013). Perkembangan Peserta Didik. Yogyakarta: UNY Press. 
Jogja, Tribun. (2016). Pelaku Bunuh Diri di Gunungkidul Didominasi Lansia. Diakses dari http://jogja.tribunnews.com pada tanggal 26 Desember 2016, jam $8: 22$ WIB.

Kemendikbud. (2005). Kamus Besar Bahasa Indonesia. Jakarta: Balai Pustaka.

Maryam, R. Siti, dkk. (2010). Asuhan Keperawatan pada Lansia. Jakarta: Trans Info Media.

Maryam, R. Siti, dkk. (2011). Mengenal Usia Lanjut dalam Perawatannya. Jakarta: Salemba Medika.

Moleong, Lexy. (2012). Metodologi Penelitian Kualitatif. Bandung: Remaja Rosdakarya.

Nugroho, Wahyudi. (200o). Keperawatan Gerontik. Jakarta: EGC.
Poerwanti, Endang \& Widodo, Nur. (2002) Perkembangan Peserta Didik. Malang: UMM Press.

Suadirman, Siti Partini. (2011). Psikologi Usia Lanjut. Yogyakarta: UGM Press.

Sugiyono. (2013). Metode Penelitian Pendidikan Pendekatan Kuantitatif, Kualitatif, dan RED. Bandung: Alfabeta.

Surbakti, E.B. (2013). Menata Kehidupan Usia Lanjut. Jakarta: Praninta Aksara.

Undang-Undang RI Nomor 13 Tahun 1998 tentang Kesejahteraan Lanjut Usia. 